\title{
A comparison between ammonium and nitrate nutrition of young sugar-beet plants grown in nutrient solutions at constant acidity. 1. Production of dry matter, ionic balance and chemical composition
}

\section{H. Breteler}

Department of Soils and Fertilizers, Agricultural University, Wageningen, the Netherlands

Accepted: 12 June 1973

\section{Summary}

In trials concerning ammonium and nitrate nutrition of sugar-beet plants changes in medium $\mathrm{pH}$ ware eliminated by automatic titration and recording of the acidity or alkalinity released during growth. Yields of the plants on both $\mathrm{N}$ forms differed by only $12 \%$ so that the effect of the $\mathrm{N}$ form on inorganic chemical composition, ionic balance, carboxylate content, soluble-sugar content and content of some nitrogenous compounds could be compared at similar yields

Cation excess (number of milliequivalents of inorganic cations minus those of inorganic anions; $\mathrm{C}-\mathrm{A}$ ) in seedlings grown on nitrate was over thrice that with ammonium.

The balance of ion uptake and the $\mathrm{H}+$ production curves showed that the acidity evolved is a good measure of the ammonium uptake. In nitrate nutrition the evolved alkalinity was small compared with the amount of nitrate absorbed by the plants and was no measure of nitrate uptake.

The diurnal changes in rate of release of $\mathrm{H}^{+}$and $\mathrm{OH}^{-}$by plants in either ammonium or nitrate nutrition were measured and related to plant composition, factors regulating ammonium and nitrate uptake, and the effect of light and darkness. There was a decrease in the rate of $\mathrm{H}^{+}$production during the dark period and a decrease in the rate $\mathrm{OH}^{-}$production during or just after the dark period.

\section{Introduction}

Sugar-beet crops are usually dressed with nitrate, which gives higher yields than ammonium (Crowther \& Garner, 1960, van Tuil, cited by Schuffelen et al., 1965). However, nitrate may be lost by leaching and denitrification, and heavy nitrogen dressings may cause high levels of nitrate and oxalate in foliage and root (Table 1).

Related species, such as spinach, mangold and fodder-beet, show similar contents when heavily dressed with nitrate (Prummel, 1966; Jurkowska, 1971; and others).

The nutritional value of crops is lowered by high nitrate and oxalate contents and with sugar-beets, a high oxalate content may be related to a low sugar content.

Sugar-beet plants grown on $\mathrm{NH}_{4}$ contain virtually no $\mathrm{NO}_{3}$ and less carboxylates than 
Table 1. Maximum nitrate and oxalate content in various parts of the sugar-beet plant sampled on various dates in a field trial with $250 \mathrm{~kg} \mathrm{~N} / \mathrm{ha}$ as $\mathrm{Ca}\left(\mathrm{NO}_{3}\right)_{2}$ (van $\mathrm{Eg}$ mond, 1973a, b).

\begin{tabular}{llllll}
\hline Plant part & \multicolumn{2}{l}{ Oxalate } & & \multicolumn{2}{l}{ Nitrate } \\
\cline { 2 - 3 } \cline { 5 - 6 } & meq/kg DM & \% of DM & & meq/kg DM & \% of DM \\
& 5800 & 26 & & 500 & 3 \\
Leaf blades & 2800 & 13 & & 2000 & 12 \\
Petioles & 600 & 3 & 330 & 2 \\
Tops & 500 & 2 & 370 & \\
Beets & & & & \\
\hline
\end{tabular}

plants grown on $\mathrm{NO}_{3}$ (Houba et al., 1971). Other factors may also be influenced by the $\mathrm{N}$ form, such as free nitrogenous compounds, $\mathrm{Na}$ and $\mathrm{K}$ in the juice affecting industrial sugar processing (Loué, 1970).

To compare the real effect of $\mathrm{NO}_{3}$ and $\mathrm{NH}_{4}$ nutrition, changes in $\mathrm{pH}$ of the substrate caused by nitrification and excess anion or cation uptake were eliminated by using a nitrification inhibitor and equipment for control of $\mathrm{pH}$.

The present experiments concern substitution of ammonium for nitrate. The major effect of this substitution, the change in the ionic balance (excess cation versus excess anion uptake) associated with $\mathrm{H}^{+}$or $\mathrm{OH}^{-}$release and the carboxylate accumulation by the plants, is considered in detail.

In addition, some aspects of nitrogen and carbohydrate metabolism are discussed.

\section{Material and methods}

Diploid sugar-beet seeds were germinated in quartz sand moistened with demineralized water. The seedlings were transferred to well-aerated nutrient solutions with either $\mathrm{NO}_{3}$ or $\mathrm{NH}_{4}$ as the source of nitrogen. The composition of the solution is given in Table 2.

Besides $\mathrm{N}$ form, the solutions differed in $\mathrm{Na}$ and $\mathrm{Cl}$ concentrations. Sodium hydroxide was added to the $\mathrm{NH}_{4}$ solution and $\mathrm{HCl}$ to the $\mathrm{NO}_{3}$ solution during $\mathrm{pH}$ control by automatic titration.

Two 60-litre PVC boxes contained nutrient solution, which was circulated by an electric pump with a capacity of 12 litres/minute (Fig. 1). At intervals of 2 to 30 weeks the solutions were renewed and the boxes and pipe system thoroughly cleaned. The solution level in the boxes was kept constant by adding demineralized water daily. $\mathrm{Ni}$ trification was effectively inhibited by the $\mathrm{N}$ serve as there was no acidification of the nutrient solution when the plants were removed and nitrate in the plants was negligible

Table 2. Composition of the nutrient solutions (meq/litre).

\begin{tabular}{llllllllll}
\hline & $\mathrm{N}_{2}+$ & $\mathrm{K}+$ & $\mathrm{Ca}^{2}+$ & $\mathrm{Mg}^{2}+$ & $\mathrm{NH}_{4}^{+}$ & $\mathrm{NO}_{3}^{-}$ & $\mathrm{Cl}$ & $\mathrm{H}_{2} \mathrm{PO}_{4}^{-}$ & $\mathrm{SO}_{4}{ }^{2}-$ \\
$\mathrm{NO}_{3}$ & 3 & 4 & 2 & 2 & 0 & 3 & 2 & 1 & 5 \\
$\mathrm{NH}_{4}$ & 2 & 4 & 2 & 2 & 3 & 0 & 7 & 1 & 5 \\
\hline
\end{tabular}

Trace elements: 0.5 ppm B, 0.5 ppm $\mathrm{Mn}, 0.4$ ppm Fe, $0.05 \mathrm{ppm} \mathrm{Zn}, 0.02 \mathrm{ppm} \mathrm{Cu,} 0.01 \mathrm{ppm} \mathrm{Mo}$, $0.01 \mathrm{ppm} \mathrm{N}$-serve (2-chloro-6-trichloromethyl pyridine). 


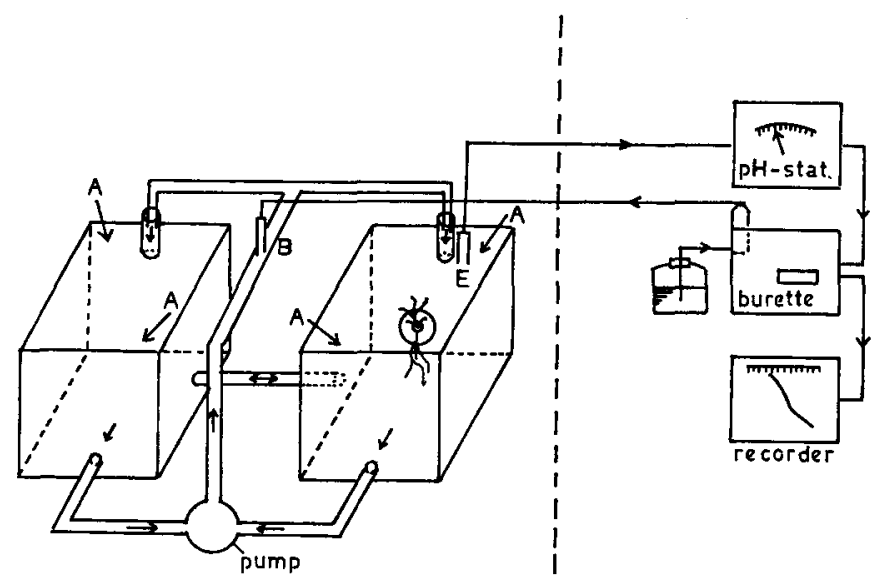

Fig. 1. Equipment for growing plants in nutrient solution at constant pH. For explanation, see text.

in ammonium nutrition. The $\mathrm{N}$ serve was added to both media and had no detectable effect on growth. The boxes were covered with perforated PVC lids in which the plants were accommodated by means of foam plastic.

The experiments were done in a growth cabinet kept at $20^{\circ} \mathrm{C}$ (night and day), a relative air humidity of $70-80 \%$, a daylength of 16 hours and a light intensity of $20000 \mathrm{~lx}$. The $\mathrm{pH}$ was regulated as outlined in Fig. 1. A glass and a reference (calomel) electrode $(E)$ were pierced through the lid of the boxes close to the point where the nutrient solution was injected. At this point mixing was severe due to the free fall of the solution and aeration (arrows A). Any change in the $\mathrm{pH}$ value of the solution was measured by a $\mathrm{pH}$-meter with $\mathrm{pH}$-stat (Radiometer,Copenhagen), preset to $\mathrm{pH} 5.50$ and operating an automatic burette with a capacity of $25 \mathrm{ml}$ and filled with $0.100 \mathrm{~N}$ $\mathrm{HCl}\left(\mathrm{NO}_{3}\right.$ nutrition), $0.100 \mathrm{~N} \mathrm{NaOH}\left(\mathrm{NH}_{4}\right.$ nutrition, young plants) or $1.00 \mathrm{~N} \mathrm{NaOH}$ $\left(\mathrm{NH}_{4}\right.$ nutrition, older plants). When the $\mathrm{pH}$ value changed, a small volume $(<0.01 \mathrm{ml})$ of acid or base was injected in the central pipe (B) to readjust it.

Damage to the plants by local high of low $\mathrm{pH}$ values was prevented by effective dilution (liquid speed at point $\mathrm{B}: 0.7 \mathrm{~m} / \mathrm{s}$ ) and mixing. The injected volumes of acid or base were integrated and recorded continuously.

\section{Analytical methods}

Inorganic cations and anions in the plants were determined as follows (Slangen, 1971). A sample of dried and ground plant material was digested in concentrated sulphuric acid and hydrogen peroxide in the presence of salicylic acid. $\mathrm{Na}, \mathrm{K}$ and $\mathrm{Ca}$ were determined flame-photometrically, $\mathrm{H}_{2} \mathrm{PO}_{4}$ colorimetrically, $\mathrm{Mg}$ by atomic absorption spectrometry and total nitrogen colorimetrically with the indophenol-blue method Another subsample was extracted with demineralized water and in the extract $\mathrm{NO}_{3}$ was determined with a nitrate electrode, $\mathrm{Cl}$ coulometrically and $\mathrm{SO}_{4}$ turbidimetrically.

Carboxylates were first converted into organic acids by decationization with a $\mathrm{H}^{+}$ sulphonic acid resin and separated by gradient elution chromatography with n-butanol/ chloroform on a silicagel column and continuous titration of the eluate. Oxalates in the 
plant residue were determined potentiometrically after extraction with $\mathrm{HCl}$ (van Egmond, 1973b). Ammonium ions, glutamine and asparagine were determined after extraction of fresh plant material with cold $70 \%$ ethanol in a cooled Bühler homogenizer. The amide groups were hydrolysed for 3 hours at $100^{\circ} \mathrm{C}$ at $\mathrm{pH} 6.5$ (glutamine) and in $1 \mathrm{~N} \mathrm{H}_{2} \mathrm{SO}_{4}$ (asparagine and glutamine).

Ammonium ions in the extract and in the hydrolysates were determined by distillation in a Parnas-Wagner apparatus and automatic titration (Breteler et al., 1972). In the same alcoholic extract total free amino compounds were estimated according to Rosen (1957), with a ninhydrin-hydrindantin mixture and dimethyl sulphoxide instead of methyl cellosolve as solvent (Moore, 1968). Results were calculated as mmoles glutamine per $\mathrm{kg}$ dry matter. Water-soluble carbohydrates were estimated after extraction under reflux with boiling demineralized water and clarification with Carrez reagents. Total water-soluble carbohydrates were determined with a Technicon autoanalyser with anthrone reagent. Glucose, fructose and sucrose were determined in the extracts by enzymatic tests (Anon., 1971): glucose by hexokinase and glucose 6-Pdehydrogenase, fructose by P-glucose-isomerase and then as for glucose, and sucrose by $\beta$-fructosidase and then as for glucose.

\section{Results}

The plants (10 per cultivation box) were grown under constant conditions for periods of about 6 weeks. Per box 5 plants were harvested, separated into leaves (tops) and roots with hypocotyledon (roots), weighed, dried at $70^{\circ} \mathrm{C}$ for $24 \mathrm{~h}$, weighed again, ground and analysed. A part of the plants was kept apart for analysis of fresh material. The roots were rinsed for 1 minute in $0.01 \mathrm{~N} \mathrm{HCl}$ and then cleaned with demineralized water. During the experiments $\mathrm{H}^{+}$or $\mathrm{OH}^{-}$production was recorded continuously. The experiments were repeated several times under the same conditions.

Experiments with one $\mathrm{N}$ source were carried out after experiments with the other. All results are averages of samples of 2 cultivation boxes (Fig. 1) and data on inorganic composition are averaged duplicates.

\section{Results}

Dry matter production

The fresh and dry weights of tops and roots of sugar-beet plants with about 15 leaves grown with nitrate or ammonium for a period of about 6 weeks is given in Table 3 .

Table 3. Fresh and dry weight (g) of tops and roots of 10 sugar-beet plants grown on different $\mathrm{N}$ sources. Age of the plants in days after transfer to the nutrient solution.

\begin{tabular}{|c|c|c|c|c|c|c|c|}
\hline \multirow{2}{*}{$\begin{array}{l}\text { Age } \\
\text { (days) }\end{array}$} & \multirow{2}{*}{$\begin{array}{l}\mathrm{N} \\
\text { source }\end{array}$} & \multicolumn{2}{|l|}{ Tops } & \multicolumn{2}{|l|}{ Roots } & \multicolumn{2}{|l|}{ Total } \\
\hline & & fresh & dry & fresh & dry & fresh & dry \\
\hline 38 & $\mathrm{NO}_{3}$ & 424 & 42 & 195 & 11 & 619 & 53 \\
\hline 42 & $\mathrm{NH}_{4}$ & 486 & 47 & 240 & 10 & 726 & 57 \\
\hline
\end{tabular}


The dry matter yield of the treatments was of similar magnitude. The small difference in age does not influence this conclusion. In 42 days at a relative growth rate of $5 \%$ per day (own observations and van Egmond \& Houba, 1970) the $\mathrm{NO}_{3}$ plants would have yielded $64 \mathrm{~g} \mathrm{DM}$ per 10 plants, which means $12 \%$ more dry matter. With this small difference the results can be considered independent of difference in yield.

\section{Inorganic chemical composition}

Results are shown in Table 4. The total inorganic cation content (C) in the tops is higher and the total inorganic anion content (A) is lower with $\mathrm{NO}_{3}$ nutrition than with $\mathrm{NH}_{4}$ nutrition. In the roots $\mathrm{A}$ was much higher in $\mathrm{NH}_{4}$ plants than in $\mathrm{NO}_{3}$ plants, and although $\mathrm{C}$ is somewhat higher, the cationic composition of the roots was the same for both nitrogen sources.

The content of monovalent and divalent cations in the tops was influenced by the $\mathrm{N}$ form in different ways. There was not much difference in cationic composition of roots and in dry matter distribution between plant parts and the corrected dry matter differed by only $12 \%$. Therefore, it can be inferred that uptake of the monovalent cations sodium and potassium was mainly repressed by ammonium nutrition (see composition whole plant). This agrees with the findings of Epstein (1962), on competitive uptake among equally charged cations. De Jaegere et al. (1963) found a decrease mainly in monovalent cation content in the roots, and in $\mathrm{Mg}$ and $\mathrm{Ca}$ content in the stems of tomato plants transferred from nitrate to ammonium medium. Data on nutrient uptake by the plants are given in Table 5 .

Table 4. Inorganic constituents and organic $\mathrm{N}$ in tops and roots and in whole sugar-beet plants after about 6 weeks growth on nitrate or ammonium medium. Contents in meq or mmol (N)/kg DM. $\mathrm{NO}_{3}$ : 38 days, $53 \mathrm{~g} \mathrm{DM} ; \mathrm{NH}_{4}: 42$ days, 57 g DM.

\begin{tabular}{|c|c|c|c|c|c|c|}
\hline & \multicolumn{3}{|l|}{$\mathrm{NO}_{3}$} & \multicolumn{3}{|l|}{$\mathrm{NH}_{4}$} \\
\hline & tops & roots & $\begin{array}{l}\text { whole } \\
\text { plant }\end{array}$ & tops & roots & $\begin{array}{l}\text { whole } \\
\text { plant }\end{array}$ \\
\hline $\mathbf{K}$ & 2003 & 1550 & 1888 & 1264 & 1582 & 1315 \\
\hline $\mathrm{Na}$ & 679 & 182 & 585 & 414 & 182 & 316 \\
\hline $\mathrm{NH}_{4}$ & 27 & 15 & 25 & 160 & 50 & 140 \\
\hline Mg & 1136 & 341 & 962 & 1025 & 374 & 948 \\
\hline $\mathrm{Ca}$ & 427 & 154 & 377 & 430 & 134 & 369 \\
\hline C & 4272 & 2242 & 3837 & 3293 & 2322 & 3088 \\
\hline $\mathrm{Cl}$ & 226 & 283 & 246 & 918 & 928 & 920 \\
\hline $\mathrm{SO}_{4}$ & 98 & 31 & 94 & 87 & 88 & 87 \\
\hline $\mathrm{H}_{2} \mathrm{PO}_{4}$ & 306 & 387 & 321 & 1296 & 708 & 1104 \\
\hline $\mathrm{NO}_{3}$ & 324 & 523 & 377 & 0 & 0 & 0 \\
\hline A & 954 & 1224 & 1038 & 2301 & 1724 & 2111 \\
\hline $\mathrm{N}_{\text {tot }}$ & 3182 & 2935 & 3152 & 4057 & 2970 & 3704 \\
\hline Norg & 2831 & 2397 & 2749 & 3897 & 2920 & 3564 \\
\hline C-A & 3318 & 1018 & 2799 & 992 & 598 & 977 \\
\hline
\end{tabular}

$\mathrm{C}=$ sum of inorganic cations in meq $/ \mathrm{kg} \mathrm{DM}$.

$\mathrm{A}=$ sum of inorganic anions in meq $/ \mathrm{kg} \mathrm{DM}$.

$N_{\text {org }}=N_{\text {tot }}-N_{\text {nitrate }}-N_{\text {ammonium }}$

Neth. J. agric. Sci. 21 (1973) 


\begin{tabular}{lrrr}
\hline & $\mathrm{NO}_{3}$ & $\mathrm{NH}_{4}$ & $\mathrm{NO}_{3} / \mathrm{NH}_{4}$ \\
$\mathrm{~K}$ & 121 & 75 & 1.61 \\
$\mathrm{Na}$ & 37 & 18 & 2.06 \\
$\mathrm{NH}$ & 1 & 8 & 0.13 \\
$\mathrm{Mg}$ & 62 & 54 & 1.15 \\
$\mathrm{Ca}$ & 24 & 21 & 1.14 \\
$\mathrm{~N}_{\text {tot }}$ & & 211 & 0.96 \\
$\mathrm{C}$ & 245 & 176 & 1.39 \\
$\mathrm{C}_{\mathrm{a}}$ & 244 & 379 & 0.64 \\
$\mathrm{Cl}$ & 16 & 52 & 0.31 \\
$\mathrm{SO}_{4}$ & 6 & 5 & 1.20 \\
$\mathrm{H}_{2} \mathrm{PO}$ & 21 & 63 & 0.33 \\
$\mathrm{NO}_{3}$ & 24 & 0 & \\
$\mathrm{~N}_{\text {tot }}$ & 202 & & 0.96 \\
$\mathrm{~A}$ & 67 & 120 & 0.56 \\
$\mathrm{~A}_{\mathrm{a}}$ & 253 & 132 & 1.92 \\
$\mathrm{C}_{-} \mathrm{A}$ & 178 & 56 & 3.18 \\
$\mathrm{C}_{\mathrm{a}}-\mathrm{A}_{\mathrm{a}}$ & & 247 & \\
$\mathrm{~A}_{\mathrm{a}}-\mathrm{C}_{\mathrm{a}}$ & 9 & & \\
$\mathrm{~N}_{\text {org }}$ & 178 & 203 & 0.88 \\
$\mathrm{~S}_{\text {org }}{ }^{*}$ & 8 & 12 & \\
\hline
\end{tabular}

Table 5. Inorganic cations, inorganic anions and nitrogen in 10 sugar-beet plants (meq or mmol (N)) after 42 days of growth on $\mathrm{NO}_{3}$ or $\mathrm{NH}_{4}$ media. The data for $\mathrm{NO}_{3}$ plants of 38 days are recalculated for 42 days, assuming relative growth rate of $5 \%$ per day, no change in shoot/root ratio, and no change in chemical composition between days 38 and 42 . The content of most inorganic constituents drops by $1 \%$ per day (Houba et al., 1971).

$\mathrm{C}, \mathrm{A}=$ sum of inorganic cations and inorganic anions in the plants, respectively.

$C_{a}, A_{a}=$ sum of inorganic cations and in organic anions absorbed by the plants, respectively.

* $\mathrm{S}_{\mathrm{org}}=\mathrm{S}_{\mathrm{tot}}-\mathrm{S}_{\mathrm{SO}_{4}}$, organic sulphur estimated as $\mathbf{N}_{\text {org }} \times 0.054$ (Dijkshoorn, 1964, de Wit et al., 1963).

In both plant parts, the anions $\mathrm{Cl}$ and $\mathrm{H}_{2} \mathrm{PO}_{4}$ were higher in concentration on ammonium than on nitrate partly because more chloride was available (Table 2). Of course the $\mathrm{NH}_{4}$ and $\mathrm{NO}_{3}$ content in the plants was influenced by the $\mathrm{N}$ source. Total nitrogen in the $\mathrm{NH}_{4}$ plants was higher than in the $\mathrm{NO}_{3}$ plants.

Higher N contents in $\mathrm{NH}_{4}$ plants (Kirkby (1968) in white mustard plants and Coïc et al. (1962) in tomato plants) may come from a lower yield caused by ambient acidification. But higher nitrogen contents in nitrate nutrition were found by Weissman (1964) in sunflower and Houba et al. (1971) in sugar-beet plants. Such data are not strictly comparable because pH control was not always effective. Data on organic $\mathrm{N}$ may be more relevant.

Welte \& Werner (1962) investigated growth and composition of several plant species at different $\mathrm{NH}_{4} / \mathrm{NO}_{3}$ ratios in the soil, established by synthetic ion exchange resins. The effect of the nitrogen source on the nitrogen content depended on plant species and plant part. With increasing $\mathrm{NH}_{4}$ supply, the $\mathrm{Ca}, \mathrm{Mg}$ and $\mathrm{K}$ contents of the leaves and the stems decreased.

Organic nitrogen values in the $\mathrm{NH}_{4}$ plants were $1000 \mathrm{meq} / \mathrm{kg} \mathrm{DM}$ (tops) or $500 \mathrm{meq} /$ $\mathrm{kg}$ (roots) higher than in the $\mathrm{NO}_{3}$ plants. As observed by many authors, the $(\mathrm{C}-\mathrm{A})$ content of nitrate plants is much higher than that of ammonium plants. Free ammonium ions are included in the (C-A) data.

Omission of $\mathrm{NH}_{4}$ from the calculation lowers (C-A) in the tops of the ammonium plants from 992 to 832 , or by $16 \%$.

\section{Nutrient absorption}

The amounts of nutrients absorbed from the solutions (DM $\times$ concentration) are given in Table 5. 
The influence of the form of $\mathrm{N}$ on the amount of inorganic elements in the plants concerns mainly the anion content, especially chloride and phosphate. Higher $\mathrm{P}$ contents were also found by DeKock (1970) in tobacco leaves grown on $\mathrm{NH}_{4}$ or urea in place of $\mathrm{NO}_{3}$. To a somewhat lesser extent the cation content too was influenced by the $\mathrm{N}$ source.

As mentioned before, replacing $\mathrm{NO}_{3}$ by $\mathrm{NH}_{4}$ affected monovalent and divalent cation liptake differently. Both total cation and anion absorption were distinctly affected by form of $\mathrm{N}$.

The $(\mathrm{C}-\mathrm{A})$ in the $\mathrm{NO}_{3}$ plants was more than three times as high as in the $\mathrm{NH}_{4}$ plants, with 122 meq more organic anions in the nitrate plants.

\section{Hydrogen and hydroxyl ion production and the ionic balance}

\section{Theory}

To keep the plant tissue electroneutral, differential cation-anion uptake is balanced by $\mathrm{OH}^{-}$or $\mathrm{H}^{+}$uptake or release. Whether electroneutrality is maintained by uptake or release of $\mathrm{H}^{+}, \mathrm{OH}^{-}$or $\mathrm{HCO}_{3}^{-}$(Dijkshoorn \& Ismunadji, 1972) is not essential as far as the ionic balance is concerned. The following equations in ion equivalents per plant are valid for the 2 forms of $\mathrm{N}$.

$\mathrm{NO}_{3}$ nutrition:

uptake of anions $=$ uptake of cations $+\mathrm{H}^{+}$uptake

$$
\begin{aligned}
& \mathrm{A}_{\mathrm{a}}=\mathrm{C}_{\mathrm{a}}+\mathrm{H}_{+}^{+} \\
& \left(\mathrm{NO}_{3}+\mathrm{Cl}+\mathrm{H}_{2} \mathrm{PO}_{4}+\mathrm{SO}_{4}\right)_{a}=(\mathrm{K}+\mathrm{Na}+\mathrm{Mg}+\mathrm{Ca})_{\mathrm{a}}+\mathrm{H}^{+}{ }_{\mathrm{a}} \\
& \text { efflux of } \mathrm{OH}^{-}=\mathrm{H}^{+}=\mathrm{A}_{\mathrm{a}}-\mathrm{C}_{\mathrm{a}} \\
& \mathrm{NH}_{4} \text { nutrition: } \\
& \text { uptake of cations }=\text { uptake of anions }+\mathrm{OH}^{-} \text {uptake } \\
& \mathrm{C}_{\mathrm{a}}=\mathrm{A}_{\mathrm{a}}+\mathrm{OH}^{-} \mathrm{a} \\
& \left(\mathrm{NH}_{4}+\mathrm{K}+\mathrm{Na}^{-} \mathrm{Mg}+\mathrm{Ca}\right)_{a}=\left(\mathrm{Cl}+\mathrm{H}_{2} \mathrm{PO}_{4}+\mathrm{SO}_{4}\right)_{\mathrm{a}}+\mathrm{OH}_{\mathrm{a}}^{-} \\
& \text {efflux of } \mathrm{H}^{+}=\mathrm{OH}^{-}=\mathrm{C}_{\mathrm{a}}-\mathrm{A}_{\mathrm{a}}
\end{aligned}
$$

Most of the nitrogenous and sulphate ions are converted into organic $\mathrm{N}$ and $\mathrm{S}$ compounds and the balance of uptake in terms of plant composition is as follows:

$\mathrm{NO}_{3}$ nutrition:

Eq. 1 yields:

$$
\begin{aligned}
& \text { efflux }\left(\mathrm{OH}^{-}\right)=\left(\mathrm{N}_{\text {org }}+\mathrm{NO}_{3}+\mathrm{NH}_{4}+\mathrm{Cl}+\mathrm{H}_{2} \mathrm{PO}_{4}+\mathrm{S}_{\text {org }}+\mathrm{SO}_{4}\right)-(\mathrm{K}+ \\
& \mathrm{Na}+\mathrm{Mg}+\mathrm{Ca})=\mathrm{N}_{\text {org }}+\mathrm{S}_{\text {org }}-(\mathrm{C}-\mathrm{A})+2 \mathrm{NH}_{4}
\end{aligned}
$$

$\mathrm{N}_{\text {org }}, \mathrm{S}_{\text {org }}, \mathrm{C}, \mathrm{A}$ and (C-A) are defined as in Tables 4 and 5, C and (C-A) inclusive $\mathrm{NH}_{4}$ ions, $\mathrm{H}_{2} \mathrm{PO}_{4}$ stands for total $\mathrm{P}$ because organic and inorganic phosphates are mainly monovalent at the common tissue $\mathrm{pH}$.

$\mathrm{NH}_{4}$ nutrition:

Eq. 2 yields:

$$
\begin{aligned}
& \text { efflux }\left(\mathrm{H}^{+}\right)=\left(\mathrm{N}_{\text {org }}+\mathrm{NH}_{4}+\mathrm{K}+\mathrm{Na}+\mathrm{Mg}+\mathrm{Ca}\right)-\left(\mathrm{Cl}+\mathrm{H}_{2} \mathrm{PO}_{4}+\mathrm{S}_{\text {org }}\right. \\
& \left.+\mathrm{SO}_{4}\right)=\mathrm{N}_{\text {org }}-\mathrm{S}_{\text {org }}+(\mathrm{C}-\mathrm{A})
\end{aligned}
$$

All diurnal $\mathrm{H}^{+}$and $\mathrm{OH}^{-}$production curves showed a decrease in rate in or shortly after the dark period and a constant rate in the light period.

Fig. 2 shows a model. To describe the influence of light and nutrients on the shape of the curves the following characteristics were applied: 


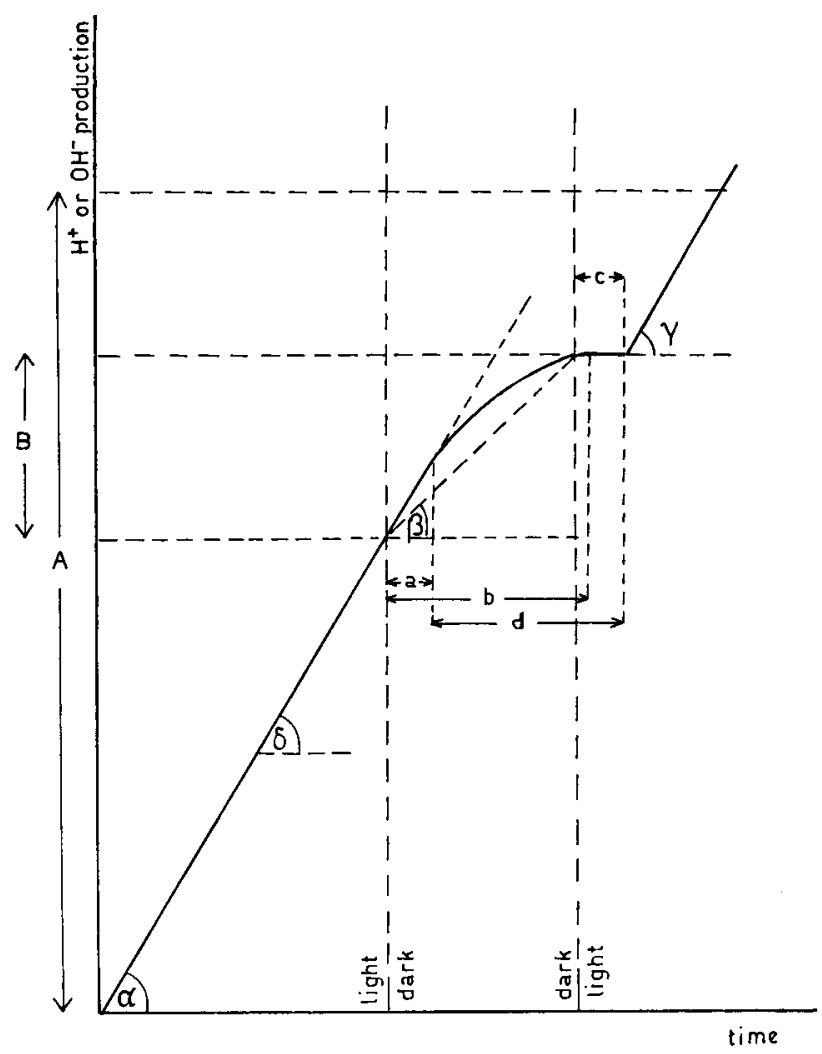

Fig. 2. Idealized shape of a daily $\mathrm{H}+$ or $\mathrm{OH}^{-}$production curve. For explanation, see text.

In units of time (minutes of hours):

a: time in which the original rate of $\mathrm{H}^{+}$or $\mathrm{OH}^{-}$production is maintained in the dark period;

b: time in which the $\mathrm{H}^{+}$or $\mathrm{OH}^{-}$production rate drops to zero after the beginning of the dark period;

c: time after the start of the light period required to restore a rate of $\mathrm{H}^{+}$or $\mathrm{OH}^{-}$ production (almost) equal to the rate in the middle of the light period (see $\delta$ );

d: shortest time interval between two (almost) equal rates of $\mathrm{H}^{+}$or $\mathrm{OH}^{-}$production. Duration of the periods fixed at $05 \mathrm{~h} 00-21 \mathrm{~h} 00$ light, $21 \mathrm{~h} 00-05 \mathrm{~h} 00$ dark.

In units of $\mathrm{H}^{+}$or $\mathrm{OH}^{-}$production (meq):

A: daily $\mathrm{H}^{+}$or $\mathrm{OH}^{--}$production, e.g. from $09 \mathrm{~h} 00$ to $09 \mathrm{~h} 00$;

B: $\mathrm{H}^{+}$or $\mathrm{OH}^{-}$produced in the dark period.

In units of $\mathrm{H}^{+}$or $\mathrm{OH}^{-}$production rate (meq/h):

$\alpha$ : rate of $\mathrm{H}^{+}$or $\mathrm{OH}^{-}$production at $09 \mathrm{~h} 00$ or any other suitable time;

$\beta$ : mean rate of $\mathrm{H}^{+}$or $\mathrm{OH}^{-}$production in the dark period;

$\gamma$ : rate of $\mathrm{H}^{+}$or $\mathrm{OH}^{-}$production after restart of acidification or alkalinization;

$\delta$ : rate at any time, e.g. if the curves are not straight; e.g., $\delta_{14}$ means $\delta$ at $14 \mathrm{~h} 00$. 
Fig. 2 is based on results with ryegrass, corn, sugar-beet, spinach and wheat under controlled and natural climatological conditions on solutions with ammonium, nitrate or both $\mathrm{N}$ forms.

\section{Results}

Substitution of the data of Table 5 in Eq. 3 and 4 yields the following results in meq per 10 plants.

$\mathrm{NO}_{3}$ nutrition: (3) efflux $\left(\mathrm{OH}^{-}\right)=178+8-178+2=10 \mathrm{meq} \mathrm{OH}^{--}$

$\mathrm{NH}_{4}$ nutrition: (4) efflux $\left(\mathrm{H}^{+}\right)=203-12+56=247 \mathrm{meq} \mathrm{H}^{+}$

Hydrogen and hydroxyl ion production integrated over the test period is represented in Fig. 3.

The results show good agreement between the recorded $\mathrm{H}^{+}$production of 250 and $\mathrm{C}_{\mathrm{a}}-\mathrm{A}_{\mathrm{a}}$ of 247 in $\mathrm{NH}_{4}$ nutrition. For nitrate nutrition the recorded $\mathrm{OH}^{-}$production of 30 ( 35 days) was at least 3 times as high as the calculated value of 9 ( 42 days). Here the difference $A_{a}-C_{a}$ is small compared with $A_{a}$ and $C_{a}$ and sampling or analytical errors are important. A $5 \%$ error in the determination of organic nitrogen or $(\mathrm{C}-\mathrm{A})$ corresponds with 9 meq $\mathrm{OH}^{-}$production. Moreover, the measurement of $\mathrm{H}^{+}$or $\mathrm{OH}^{-}$ production was less accurate in the first week.

Fig. 4 shows a considerable daily variation in $\mathrm{H}^{+}$and $\mathrm{OH}^{-}$production rate. At the

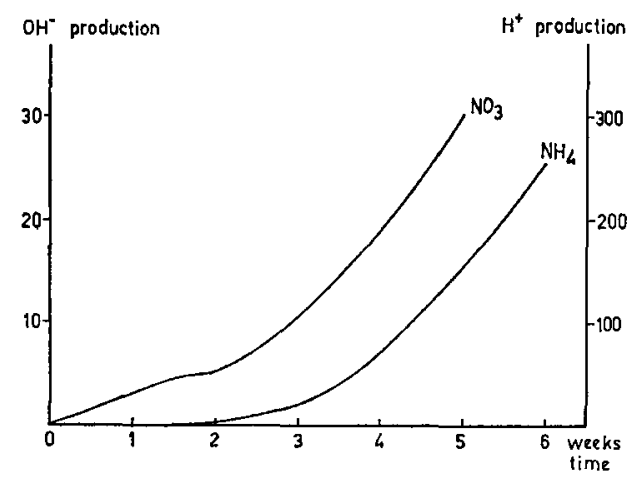

Fig. 3. Cumulative $\mathrm{H}+\left(\mathrm{NH}_{4}\right.$ nutrition $)$ and $\mathrm{OH}^{-}\left(\mathrm{NO}_{3}\right.$ nutrition) production expressed as meq per 10 plants in the course of time.

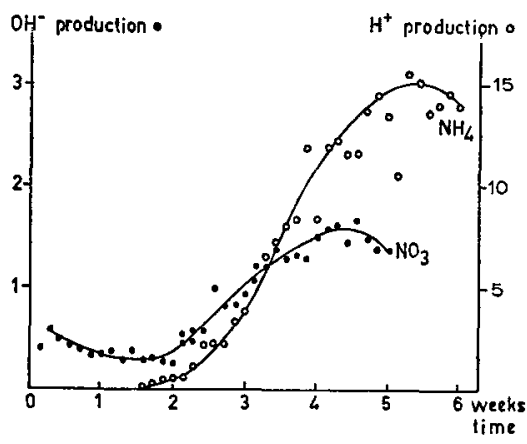

Fig. 4. The daily production rate of $\mathrm{OH}^{-}\left(\mathrm{NO}_{3} \mathrm{nu}-\right.$ trition) and $\mathrm{H}+\left(\mathrm{NH}_{4}\right.$ nutrition) ions, expressed as meq per 10 plants per day (09h00-09h00). 
end of the test the rate decreased with both nitrogen sources. The $\mathrm{H}^{+}$or $\mathrm{OH}^{-}$production lines are not always straight as drawn in Fig. 2 (see following figures). The decrease in rate is not always to zero rate, while this may be reached within the dark period as well. Decrease in $\mathrm{H}^{+}$or $\mathrm{OH}^{-}$production depends on plant species, stage of development, photoperiod etc. Of course more characteristics of the diurnal pattern of $\mathrm{H}^{+}$or $\mathrm{OH}^{-}$production could be derived from the curves, but then little is gained in view of the large variation in rate from day to day (see Fig. 4 where the daily production is plotted against time).

The diurnal pattern of $\mathrm{OH}^{-}$production by plants grown on nitrate medium for 20 , 30 or 42 days is given in Fig. 5, 6 and 7. With age a (time interval in which $21 \mathrm{~h} 00$ production rate is maintained), b (time from $21 \mathrm{~h} 00$ to zero production), A (daily pro-
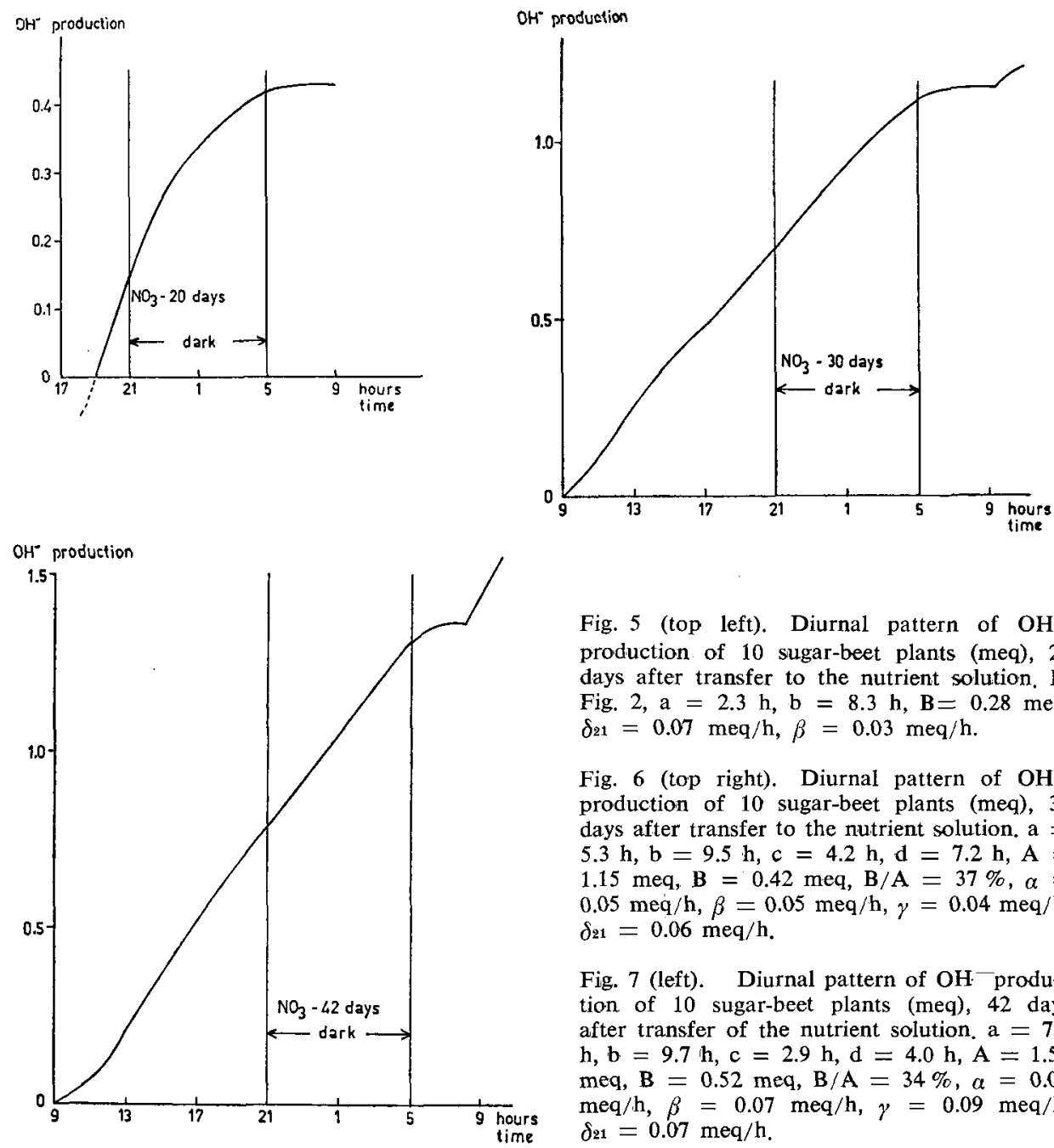

Fig. 5 (top left). Diurnal pattern of $\mathrm{OH}^{-}$ production of 10 sugar-beet plants (meq), 20 days after transfer to the nutrient solution. In Fig. 2, $\mathrm{a}=2.3 \mathrm{~h}, \mathrm{~b}=8.3 \mathrm{~h}, \mathrm{~B}=0.28 \mathrm{meq}$, $\delta_{21}=0.07 \mathrm{meq} / \mathrm{h}, \beta=0.03 \mathrm{meq} / \mathrm{h}$.

Fig. 6 (top right). Diurnal pattern of $\mathrm{OH}^{-}$ production of 10 sugar-beet plants (meq), 30 days after transfer to the nutrient solution, $\mathrm{a}=$ $5.3 \mathrm{~h}, \mathrm{~b}=9.5 \mathrm{~h}, \mathrm{c}=4.2 \mathrm{~h}, \mathrm{~d}=7.2 \mathrm{~h}, \mathrm{~A}=$ $1.15 \mathrm{meq}, \mathbf{B}=0.42 \mathrm{meq}, \mathrm{B} / \mathrm{A}=37 \%, \alpha=$ $0.05 \mathrm{meq} / \mathrm{h}, \beta=0.05 \mathrm{meq} / \mathrm{h}, \gamma=0.04 \mathrm{meq} / \mathrm{h}$, $\delta_{21}=0.06 \mathrm{meq} / \mathrm{h}$.

Fig. 7 (left). Diurnal pattern of $\mathrm{OH}^{-}$production of 10 sugar-beet plants (meq), 42 days after transfer of the nutrient solution. $\mathrm{a}=7.3$ $\mathrm{h}, \mathrm{b}=9.7 \mathrm{~h}, \mathrm{c}=2.9 \mathrm{~h}, \mathrm{~d}=4.0 \mathrm{~h}, \mathrm{~A}=1.54$ meq, $\mathrm{B}=0.52 \mathrm{meq}, \mathrm{B} / \mathrm{A}=34 \%, a=0.04$ $\mathrm{meq} / \mathrm{h}, \beta=0.07 \mathrm{meq} / \mathrm{h}, \gamma=0.09 \mathrm{meq} / \mathrm{h}$, $\delta_{21}=0.07 \mathrm{meq} / \mathrm{h}$. 
duction), B (production in the dark), $\beta$ (mean dark production rate), $\gamma$ (regained rate) and $\delta_{21}$ (production rate at the end of the light period) increase, while c (time from $05 \mathrm{~h} 00$ to production restart) and d (time interval between two high production rates) decrease. The initial slope at $21 \mathrm{~h} 00\left(\delta_{21}\right)$ is maintained for at least several hours of darkness while the rate of $\mathrm{OH}^{-}$production does not fall to zero until early in the subsequent light period. In general, the older the plants were, the longer the $\mathrm{OH}^{-}$production rate concluding the light period $\left(\delta_{21}\right)$ was maintained in darkness and the longer the plants took to completely stop $\mathrm{OH}^{-}$production.

Young plants had longer periods with zero production rates than older plants.
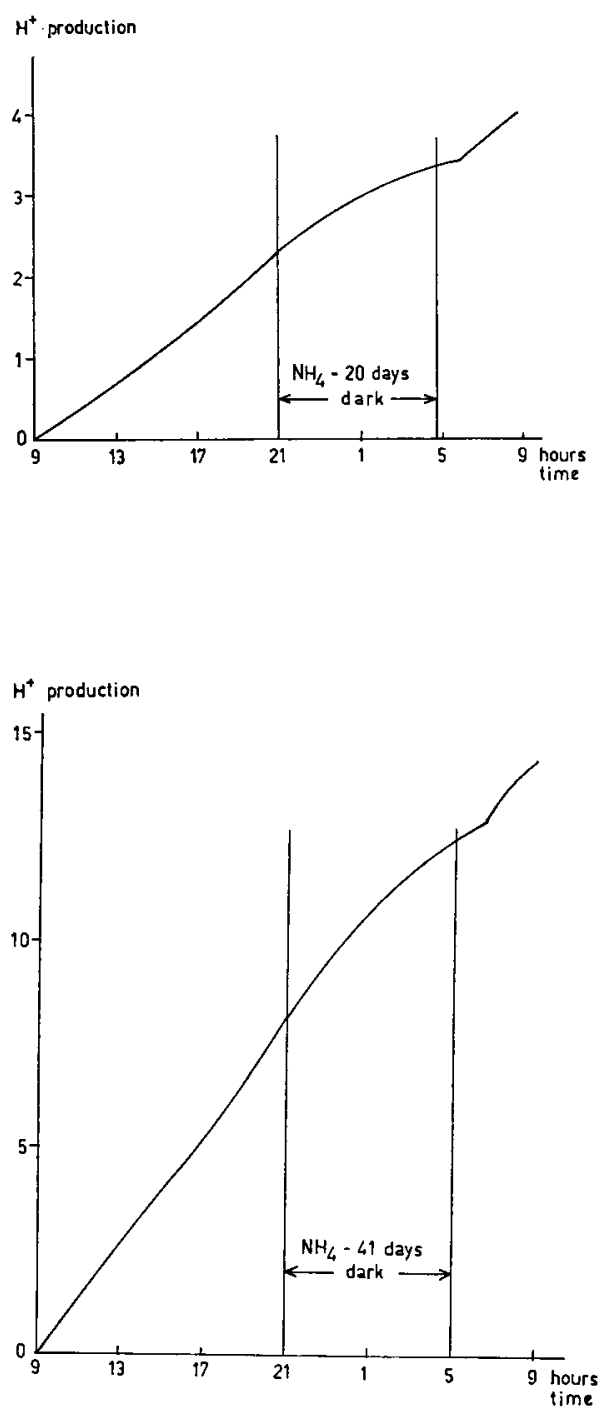

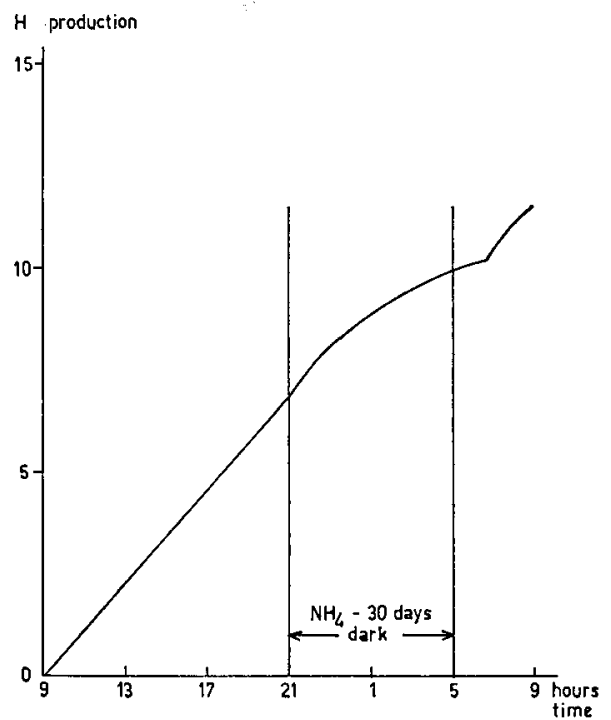

Fig. 8 (top left). Diurnal pattern of $\mathbf{H}+$ production of 10 sugar-beet plants (meq), 20 days after transfer to the nutrient solution. $\mathrm{a}=0.9 \mathrm{~h}, \mathrm{c}=$ $1.2 \mathrm{~h}, \mathrm{~d}=8.1 \mathrm{~h}, \mathrm{~A}=4.1 \mathrm{meq}, \mathrm{B}=1.1 \mathrm{meq}$, $\mathrm{B} / \mathrm{A}=27 \%, \alpha=0.16 \mathrm{meq} / \mathrm{h}, \beta=0.14 \mathrm{meq} / \mathrm{h}$, $\gamma=0.20 \mathrm{meq} / \mathrm{h}, \delta \mathrm{21}=0.20 \mathrm{meq} / \mathrm{h}$.

Fig. 9 (top right). Diurnal pattern of $\mathbf{H}+$ production of 10 sugar-beet plants (meq), 30 days after transfer to the nutrient solution. $\mathrm{a}=2.0 \mathrm{~h}, \mathrm{c}=$ $1.6 \mathrm{~h}, \mathrm{~d}=7.6 \mathrm{~h}, \mathrm{~A}=11.5 \mathrm{meq}, \mathrm{B}=3.0 \mathrm{meq}$, $\mathrm{B} / \mathrm{A}=26 \%, \alpha=0.6 \mathrm{meq} / \mathrm{h}, \beta=0.4 \mathrm{meq} / \mathrm{h}$, $\gamma=0.6 \mathrm{meq} / \mathrm{h}, \delta_{21}=0.6 \mathrm{meq} / \mathrm{h}$.

Fig. 10 (left). Diurnal pattern of $\mathbf{H}+$ production of 10 sugar-beet plants (meq), 41 days after transfer to the nutrient solution. $\mathrm{a}=1.8 \mathrm{~h}, \mathrm{c}=1.6 \mathrm{~h}$, $\mathrm{d}=7.8 \mathrm{~h}, \mathrm{~A}=14.4 \mathrm{meq}, \mathrm{B}=4.4 \mathrm{meq}, \mathrm{B} / \mathrm{A}=$ $31 \%, \alpha=0.7 \mathrm{meq} / \mathrm{h}, \beta=0.5 \mathrm{meq} / \mathrm{h}, \gamma=0.6$ $\mathrm{meq} / \mathrm{h}, \delta_{21}=0.7 \mathrm{meq} / \mathrm{h}$. 
The increase in total daily production is shown by Fig. 4. The ratio B : A was close to $8: 24$ indicating a small effect of the dark period on the total daily $\mathrm{OH}^{-}$production. Darkness affects the $\mathrm{OH}^{-}$production obviously early in the subsequent light period.

The curves show that the older plants were, the less darkness affected $\mathrm{OH}^{-}$production.

The diurnal $\mathrm{H}^{+}$production by plants on the ammonium medium for 20,30 or 41 days is given in Fig. 8, 9 and 10. With increase in age its pattern was fairly constant. $\mathrm{A}, \mathrm{B}$ and related characteristics $\alpha, \beta$ etc. increase (see Fig. 4), c tends to increase and a tends to decrease. Production of $\mathrm{H}^{+}$ions does not stop completely in or after the dark period. With increasing age $\mathrm{H}^{+}$production of the plants seems to be more affected by darkness. On nitrate, $\mathrm{OH}^{-}$production became less light-dependent in the course of growth.

Compared with the $\mathrm{OH}^{-}$production curves the slope of the curve decreases earlier after darkness (a: 1-2 $\mathrm{h}$ for $\mathrm{NH}_{4}, 2-7 \mathrm{~h}$ for $\mathrm{NO}_{3}$ ). This reflected in the $\mathrm{B}$ : A ratio, which is lower than $8: 24$ for $\mathrm{NH}_{4}$ nutrition.

On nitrate medium there is also some decrease in slope in the dark but the slope at $21 \mathrm{~h} 00\left(\delta_{21}\right)$ is maintained so long that the B : A ratio is equal to or higher than $8: 24$ because the zero rate of $\mathrm{OH}^{-}$production is found early in the light period. From Fig. 5 to 10 it can be concluded that the $\mathrm{H}^{+}$production rate was more light-affected than $\mathrm{OH}^{-}$ production since the effect of darkness is earlier observed, although there is no complete stop in $\mathrm{H}^{+}$production, as for $\mathrm{OH}^{-}$production.

Trends in the curve characteristics with age as decribed for $\mathrm{NH}_{4}$ or $\mathrm{NO}_{3}$ nutrition were averaged from all daily recording sheets. It is not useful to represent all daily graphs, which differed appreciably. For instance in the $\mathrm{NH}_{4}$ experiment values for a varied between 32 and 128 minutes and for c between 20 and 136 minutes.

\section{Carboxylates}

Any excess of inorganic cations over inorganic anions (C-A) within plants is balanced by carboxylate anions. Table 6 shows contents of the detected carboxylates in the tops, roots and the whole plants.

Table 6. Carboxylates and (C-A) in tops, roots and whole sugar-beet plants grown for 6 weeks on nitrate or ammonium medium. Contents in meq $/ \mathrm{kg} \mathrm{DM}$, (C-A) from Table 4. $\mathrm{NO}_{3}: 38$ days, $53 \mathrm{~g} \mathrm{DM} ; \mathrm{NH}_{4}: 42$ days, $57 \mathrm{~g} \mathrm{DM}$.

\begin{tabular}{|c|c|c|c|c|c|c|}
\hline & \multicolumn{3}{|l|}{$\mathrm{NO}_{3}$} & \multicolumn{3}{|l|}{$\mathrm{NH}_{4}$} \\
\hline & tops & roots & $\begin{array}{l}\text { whole } \\
\text { plant }\end{array}$ & tops & roots & $\begin{array}{l}\text { whole } \\
\text { plant }\end{array}$ \\
\hline Fumarate & 8 & 12 & 9 & 12 & 12 & 12 \\
\hline Succinate & 8 & 8 & 8 & 8 & 10 & 8 \\
\hline Malonate & 28 & 16 & 26 & 14 & 16 & 14 \\
\hline Oxalate & 2412 & 920 & 2102 & 1045 & 990 & 1037 \\
\hline Malate & 60 & 31 & 54 & 42 & 16 & 37 \\
\hline Citrate & 184 & 228 & 193 & 38 & 26 & 35 \\
\hline Sum & 2700 & 1215 & 2392 & 1159 & 1070 & 1143 \\
\hline (C-A) & 3318 & 1018 & 2799 & 992 & 598 & 977 \\
\hline
\end{tabular}


The carboxylate content of the plants parallels the (C-A) contents of Table 4, with the highest contents in $\mathrm{NO}_{3}$ plants. Tops of nitrate plants have higher carboxylate contents than roots. In many plant species, nitrate metabolism takes place mainly in the leaves (Beevers \& Hageman, 1969; Ben Zioni et al., 1971) and a part of the carboxylates generated during nitrate reduction (in sugar-beet plants mainly oxalates) moves downward. Of the carboxylates in the $\mathrm{NO}_{3}$ plants $11 \%$ was present in the roots. $\mathrm{NH}_{4}$ uptake influences the carboxylate pool so that it is always low due to rapid extraction of keto acids and the formation of organic nitrogen compounds (Wakiuchi et al., 1971).

The synthesis of organic $\mathrm{N}$ compounds in the dry matter of nitrate plants (e.g. mmol $\mathrm{N}_{\text {o:g }} / \mathrm{kg} \mathrm{DM}$ ) proceeds at a slower rate due to the rate controlling nitrate reduction. The difference between the carboxylate content in tops and roots of $\mathrm{NH}_{4}$ plants is small compared with the difference in nitrate plants. This may be because production of organic $\mathrm{N}$ is not restricted to the tops in $\mathrm{NH}_{4}$ plants. In these plants $20 \%$ of the carboxylates are present in the roots. Lower contents of citrate and malate in $\mathrm{NH}_{4}$ plants than in $\mathrm{NO}_{3}$ plants may indicate that oxaloacetic acid is an important keto acid in the nitrogen assimilation process in sugar-beet plants. The high oxalate contents in the $\mathrm{NH}_{4}$ plants show that oxalate is also readily synthesized in ammonium nutrition.

\section{Carbohydrates}

Total water-soluble carbohydrates, glucose, fructose and sucrose in different plant parts and in whole plants grown on $\mathrm{NO}_{3}$ or $\mathrm{NH}_{4}$ medium are listed in Table 7 . It is clear that ammonium has a depressive effect on the water-soluble carbohydrate content in both plant parts. As there is no notable concentration effect caused by growht difference between the media, this observation confirms the idea that $\mathrm{NH}_{4}$ nutrition leads to a depletion of carbohydrate reserves in the plant (Kirkby \& Hughes, 1970; Mulder, 1956). Differential soluble-carbohydrate consumption under the two $\mathrm{N}$ regimes may explain why $\mathrm{OH}^{-}$production becomes less and $\mathrm{H}^{+}$production more light-affected with increase in plant age. Concentrations of reducing sugars in the plant are not altered as much as the total soluble-carbohydrate pool by the kind of nitrogen supply. Of course, the test plants are not comparable with full-grown sugar-beet plants, but it should be noticed that nitrate plants contain more than twice as much soluble carbohydrates as ammonium plants. Sucrose content is also higher in nitrate nutrition.

Table 7. Total water-soluble carbohydrates, glucose, fructose and sucrose content (\% of DM) of tops, roots and of whole sugar-beet plants grown for a period of about 6 weeks on nitrate or ammonium medium. $\mathrm{NO}_{3}$ : 38 days, $53 \mathrm{~g} \mathrm{DM} ; \mathrm{NH}_{4}: 42$ days, 57 g DM.

\begin{tabular}{|c|c|c|c|c|c|c|}
\hline & \multicolumn{3}{|l|}{$\mathrm{NO}_{3}$} & \multicolumn{3}{|l|}{$\mathbf{N} \cdot \mathrm{H}_{4}$} \\
\hline & tops & roots & $\begin{array}{l}\text { whole } \\
\text { plant }\end{array}$ & tops & roots & $\begin{array}{l}\text { whole } \\
\text { plant }\end{array}$ \\
\hline Glucose & 0.58 & 0.85 & 0.63 & 0.38 & 0.40 & 0.38 \\
\hline Fructose & 0.27 & 0.40 & 0.30 & 0.49 & 0.33 & 0.47 \\
\hline $\begin{array}{l}\text { Glucose }+ \\
\text { fructose }\end{array}$ & 0.85 & 1.25 & 0.93 & 0.87 & 0.73 & 0.85 \\
\hline Sucrose & 4.24 & 4.28 & 4.25 & 2.98 & 2.51 & 2.90 \\
\hline Total & 10.3 & 8.9 & 10.0 & 4.7 & 3.9 & 4.6 \\
\hline
\end{tabular}




\section{Free nitrogenous compounds}

The content of ammonium ions, free glutamine, asparagine and amino acids is given in Table 8. Contents in $\mathrm{DM}$ and as $\%$ of total $\mathrm{N}$ are higher in ammonium nutrition than in nitrate nutrition and most of the free $\mathrm{N}$ is in the amides. With $\mathrm{NH}_{4}$ the value of the glutamine/asparagine quotient is higher than with nitrate. The content of ammonium ions in both tops and roots may be high and comparable to values for sulphate, sodium and calcium in plant parts.

It is clear that $\mathrm{NH}_{4}$ should be included in the calculation of (C-A) particularly in $\mathrm{NH}_{4}$ plants. In contrast to the situation in gramineous plants like rice (Zsoldos, 1962) and wheat (Breteler, unpublished data) the $\mathrm{NH}_{4}$ content in the tops is higher than in the roots in dry as well as in fresh material.

$\mathrm{NH}_{4}$ and the free nitrogenous metabolites are considerably higher in tops than in roots of $\mathrm{NO}_{3}$ plants, while they are on the same level in tops and roots of $\mathrm{NH}_{4}$ plants, suggesting that nitrate is metabolized by the aerial parts. The data on free $\mathrm{N}$ compounds and carboxylates (Table 6) show that the carboxylate content and the free amino acid and amide content in tops of $\mathrm{NO}_{3}$ plants are three times as high as in roots.

It is also clear that a higher organic $\mathrm{N}$ content is associated with a lower carbohydrate content, because the latter compounds supply $\mathrm{C}$ skeletons for the synthesis of the amino acids.

Table 8. Ammonium, soluble amides and amino acids in tops, roots and in whole 6-week old sugar-beet plants grown on nitrate or ammonium medium. Content in meq $\mathrm{NH}_{4}+/ \mathrm{kg} \mathrm{DM}, \mathrm{mmol} / \mathrm{kg} \mathrm{DM}$ (amides) and mmol N/ $\mathrm{kg} \mathrm{DM}$ (amino acids and amides). $\mathrm{NO}_{3}: 38$ days, $53 \mathrm{~g} \mathrm{DM} ; \mathrm{NH}_{4}: 42$ days, $57 \mathrm{~g} \mathrm{DM}$.

\begin{tabular}{|c|c|c|c|c|c|c|}
\hline & \multicolumn{3}{|l|}{$\mathrm{NO}_{3}$} & \multicolumn{3}{|l|}{$\mathrm{NH}_{4}$} \\
\hline & tops & roots & $\begin{array}{l}\text { whole } \\
\text { plant }\end{array}$ & tops & roots & $\begin{array}{l}\text { whole } \\
\text { plant }\end{array}$ \\
\hline $\mathrm{NH}_{4}$ & 27 & 15 & 25 & 123 & 74 & 114 \\
\hline Glu. $\mathbf{N H}_{2}$ & 63 & 10 & 52 & 141 & 149 & 143 \\
\hline Asp. $\mathrm{NH}_{2}$ & 76 & 38 & 68 & 47 & 55 & 48 \\
\hline Glu. $\mathrm{NH}_{2}+$ Asp. $\mathrm{NH}_{2}$ & 139 & 48 & 120 & 188 & 204 & 191 \\
\hline Glu. $\mathrm{NH}_{2} /$ Asp. $\mathrm{NH}_{2}$ & 0.83 & 0.26 & 0.71 & 3.00 & 2.71 & 2.95 \\
\hline Amino acids and amides & 317 & 102 & 272 & - & - & $471 *$ \\
\hline Amino acid-N and amide-N & & & & & & \\
\hline as $\%$ of total $\mathrm{N}$ & 10 & 3 & 9 & - & - & 13 \\
\hline
\end{tabular}

* As no data were available, the contents in whole plants of additional experiments are represented (Breteler, 1973).

\section{Discussion}

\section{Plant nutritional aspects}

The relatively small difference in dry matter production on nutrient solutions with ammonium and nitrate in the present experiment is due to the control of the nutrient solution $\mathrm{pH}$. In most other experiments without $\mathrm{pH}$ control sugar-beets and other plants 
yielded less dry matter on $\mathrm{NH}_{4}$ medium than on $\mathrm{NO}_{3}$ medium. The present results could not support the view that there exists a normal (C-A) content, required for optimum growth (van Tuil, 1965; Dijkshoorn, 1964; de Wit et al., 1963), because the low relative growth rate indicates that growth was far from optimum and did not change with the large difference in carboxylate content between treatments.

Chouteau (1963) found that tobacco plants grown on $\mathrm{NH}_{4}$ had the same dry matter production as on $\mathrm{NO}_{3}$, if he added 12 meq $\mathrm{HCO}_{3}-$ per litre. The $\mathrm{pH}$ was adjusted with acid so that there was a certain control of acidity. Other techniques for plant growth at controlled $\mathrm{pH}$ have been described by Audus (1949), Pitman (1970), Kirkby \& Hughes (1970), Weissman (1972) and others.

None of the described techniques unifies the advantage of $\mathrm{pH}$ maintenance with continuous registration of the hydrogen or hydroxyl ion production.

Eq. 4 shows that of the $247 \mathrm{meq} \mathrm{H}^{+}$released by 10 plants, 203 originate from organic nitrogen and 8 from apparently unmetabolized $\mathrm{NH}_{4}$ ions, $86 \%$ being due to uptake of $\mathrm{NH}_{4}$ ions and $14 \%$ to the uptake of non-nitrogenous cations over anions. Dijkshoorn \& Ismunadji (1972) found for the shoots of rice plants grown on $\mathrm{NH}_{4} \mathrm{me}$ $\operatorname{dium} \mathrm{N}_{\text {org }}=320 \mathrm{meq}$ and $(\mathrm{C}-\mathrm{A})=63$ meq per 4 plants, which means that although free ammonium ions were not taken into account $84 \%$ of the corresponding acidification was caused by $\mathrm{NH}_{4}$ absorption. In other plants (e.g. oil palm and corn) we found this percentage always between 85 and 90 .

Therefore the $\mathrm{H}^{+}$production is roughly equivalent to the $\mathrm{NH}_{4}$ uptake and this is the more true if the excess uptake of non-nitrogenous cations of anions varies in proportion to the $\mathrm{NH}_{4}$ uptake, so that the proportion of total acidification caused by $\mathrm{NH}_{4}$ uptake is constant. This would make the equipment for $\mathrm{pH}$ control a recording ammonium electrode, helpful in research on $\mathrm{NH}_{4}$ uptake.

There is no reliable ion specific electrode for ammonium, the present electrodes are still too sensitive to $\mathrm{K}^{+}$and $\mathrm{H}^{+}$(Simon et al., 1970).

Reading $\mathrm{NH}_{4}$ uptake for $\mathrm{H}^{+}$production allows the following conclusions.

1. Ammonium uptake per plant increases with time (Fig. 3) and the daily $\mathrm{NH}_{4}$ uptake per plant reaches a maximum between 5 and 6 weeks after transfer to the nutrient solution (Fig. 4). Decreased ammonium uptake may be related to the onset of beet growth and internal redistribution of nitrogen.

2. The ammonium uptake rate decreases in the dark period (1-2 hours after darkness) but not to zero. About $11 / 2$ hours after reillumination the effect of the dark is overshaded by the effect of light (Fig. 8, 9 and 10). Under the present experimental conditions the $\mathrm{NH}_{4}$ uptake per plant per hour was almost constant in the light period.

3. In a normal diurnal cycle the sugar-beet plants did not completely stop $\mathrm{H}^{+}$production ( $\mathrm{NH}_{4}$ uptake). This result is contradictory to the view of Prianishnikov (1951) that young sugar-beet plants are strongly dependent on carbohydrate of light for their ammonium absorption because of their carbohydrate poverty. In gramineous plants like corn, perennial ryegrass and wheat (Breteler, unpublished data) a decrease to zero rate of $\mathrm{H}^{+}$production in the dark period was observed under exactly the same climatological conditions.

Recently some authors (Pitman, 1970, and others) related $\mathrm{H}^{+}$production by plants to the ion uptake process. For this purpose the experimental technique I described offers facilities, because it can be used in small scale and short-term experiments as well (Breteler, unpublished data).

Pitman found a hydrogen ion production by excised low-salt barley roots from 50 to $250 \times 10^{-6}$ meq per $\mathrm{g}$ fresh root per hour at $\mathrm{pH} 5.3$ and $600 \times 10^{-6} \mathrm{meq}$ at $\mathrm{pH} 4.2$. 
Maximum $\mathrm{H}^{+}$production in the present experiments was 20 to 30 meq per 10 plants per day at $\mathrm{pH} 5.5$ corresponding with about $400 \times 10^{-6}$ meq per $\mathrm{g}$ fresh root per hour. This figure fits in between the two maximum rates measured by Pitman. As far as the production of $\mathrm{OH}^{-}$is concerned there is no possibility (Eq. 3) of relating the curves to nitrate uptake. It is known that in sugar-beet plants grown with nitrate the contents of organic nitrogen and (C-A) are roughly equivalent (Houba et al., 1971), in other plant species the possibility of relating $\mathrm{OH}^{-}$release to some extent with $\mathrm{NO}_{3}$ uptake may be considered. Of course one must realize that the $\mathrm{H}^{+}$or $\mathrm{OH}^{-}$production is never caused by the uptake of one single ion but by the difference in positively charged and negatively charged ions. It was observed that with the increase of age the $\mathrm{OH}^{-}$production became less and the $\mathrm{H}^{+}$production affected by darkness.

Michael et al. (1970) found that the carbohydrate content of sugar-beet roots decreased with age. A great difference in soluble-carbohydrate content (Table 7) under influence of the two $\mathrm{N}$ forms after about six weeks growth was observed. These findings suggest a strong mutual effect between the uptake of nitrogen in the form of $\mathrm{NH}_{4}$ or $\mathrm{NO}_{3}$ and the carbohydrate reserve.

A question that rises is: what is the effect of respiration on the apparent $\mathrm{H}^{+}$or $\mathrm{OH}^{-}$ production? At $\mathrm{pH} 5.50$ nearly all the carbon dioxide released by root respiration is in the form of $\mathrm{H}_{2} \mathrm{CO}_{3}$ and not in the form of $\mathrm{HCO}_{3}{ }^{-}$and a possible effect of respiration remains small.

If $\mathrm{CO}_{2}$ production had an effect than the $\mathrm{pH}$ value should have changed because of the interference of $\mathrm{CO}_{2}$ from the air when the system runs without plants. This change in $\mathrm{pH}$ was never observed.

\section{Practical aspects}

Some practical aspects are summarized in Table 9. The properties of the mature sugarbeets were predicted from characteristics of the 6-week old plants, used in the present experiments.

Of course it must be realized that dry matter yields under field conditions have been reported to be unequal between the two considered nitrogen sources and that fertilizer leaching, nitrification and soil acidification interferes. It is concluded that taking all aspects of $\mathrm{NO}_{3}$ and $\mathrm{NH}_{4}$ nutrition together nitrate is a better $\mathrm{N}$ source for beet sugar

Table 9. Predictions for some properties of sugar-beets grown on $\mathrm{NH}_{4}$ or $\mathrm{NO}_{3}$ based on the results of the present water culture experiments. $+=$ favourable; $-=$ unfavourable.

\begin{tabular}{lcc}
\hline Feature & $\mathrm{NO}_{3}$ & $\mathrm{NH}_{4}$ \\
Dry matter yield & + & + \\
Sugar content & + & - \\
Sugar yield & + & - \\
Harmful N content & + & - \\
$\mathrm{Na}$ and K content & - & + \\
Oxalate content & - & + \\
$\mathrm{NO}_{3}$ content & - & + \\
\hline
\end{tabular}


production than ammonium. This conclusion was drawn long ago in agricultural pras tice.

For related crops not grown for sugar, however, it is possible that, depending on th: specific quality characteristics, $\mathrm{NH}_{4}$ may be as good a nitrogen source as $\mathrm{NO}_{3}$.

\section{Acknowledgment}

I wish to thank Mr E. M. Wittich and Mr M. Stuart for their skilful analytical and technical assistance and Dr W. Dijkshoorn and Dr A. C. Schuffelen for their critical comments on the text. I am indebted to Ir F. van Egmond for valuable discussions. which resulted in the described $\mathrm{pH}$ control technique and for critically reviewing the text. I thank Mrs E. Brouns for correction of the English text.

\section{References}

Anonymous, 1971. Enzymatische Analysen für die Lebensmittelchemie. Boehringer Mannheim Biochemica.

Audus, L. J., 1949. Studies on the pH-relationships of roots growth and its inhibition by $2: 4$ dichlorophenoxyacetic acid and coumarin. New Plyytol. 48: 97-114.

Beevers, L. \& R. H. Hageman, 1969. Nitrate reduction in higher plants. A. Rev. Pl. Physiol. 20: $495-522$.

Ben Zioni, A., Y. Vaadia \& S. H. Lips, 1971. Nitrate uptake by roots as regulated by nitrate reduction products of the shoot. Physiologia Pl. 24: 288-290.

Breteler, H., E. M. Wittich \& W. H. Frentz, 1972. De bepaling van vrije asparagine, glutamine en ammonium in plantaardig materiaal. Interne Meded. Lab. Landb. Scheik. No 4.

Breteler, H., 1973. A comparison between ammonium and nitrate nutrition of young sugar-beet plants grown in nutrient solutions at constant acidity. 2. Effect of light and carbohydrate supply. Neth. J. agric. Sci. (in prep.).

Chouteau, J., 1963. Etude de la nutrition nitrique et ammoniacale de la plante de tabac en présence des doses croissantes de bicarbonate dans le milieu nutritif. Ann. Inst. Exp. Tabac Bergerac 4, No 2.

Coïc, Y., Ch. Lesaint \& F. Le Roux, 1962. Effets de la nature ammoniacale ou nitrique de l'alimentation azotée et du changement de la nature de cette alimentation sur le métabolisme des anions et cations chez la tomate. Annls. Physiol. vég. 4: 117-125.

Crowther, E. M. \& H. V. Garner, 1960. Cited in The nitrogenous fertilization of sugar-beet. Chilean Nitrate Agric. Serv. Inf. No 47.

DeKock, P. C., 1970. The mineral nutrition of plants supplied with nitrate or ammonium nitrogen. In: E. A. Kirkby (Ed.), Nitrogen nutrition of the plant, p. 39-44. University of Leeds.

Dijkshoorn, W., 1964. Le bilan ionique dans le diagnostic foliaire. Jaarb. Inst. biol. scheik. Onderz. Landb. Gew. 1964: 133-144.

Dijkshoorn, W. \& M. Ismunadji, 1972. Nitrogen nutrition of rice plants measured by growth and nutrient content in pot experiments. 3. Changes during growth. Neth. J. Agric. Sci. 20: 133-144.

Egmond, F. van, 1973a. Inorganic cations and carboxylates in young sugar-beet plants. In: Potassium in biochemistry and physiology, p. 104-117. International Potash Institute, Berne Switzerland.

Egmond, F. van, 1973b. Thesis, Wageningen (in preparation).

Egmond, F. van \& V. J. G. Houba, 1970. Production of carboxylates (C-A) by young sugar-beet plants grown in nutrient solutions. Neth. J. Agric. Sci. 18: 182-187.

Epstein, E., 1962. Mutual effect of ions in their absorption by plants. Agrochimica 6: 293-322.

Houba, V. J. G., F. van Egmond \& E. M. Wittich, 1971. Changes in production of organic nitrogen and carboxylates (C-A) in young sugar-beet plants grown in nutrient solutions of different nitrogen composition. Neth. J. Agric Sci. 19: 39-47.

Jaegere, R. de, Ch. Lesaint \& Y. Coïc, 1963. Sur l'excrétion d'ions minéraux: influence du changement de nature de l'alimentation azotée. Annls. Physiol. vég. 5: 263-276.

Jurkowska, H., 1971. Effect of dicyanodiamide on the content of nitrates and oxalic acid in spinach. Agrochimica 15: 445-453. 
Kirkby, E. A., 1968. Influence of ammonium and nitrate nutrition on the cation-anion balance and nitrogen and carbohydrate metabolism of white mustard plants grown in dilute nutrient solutions. Soil Sci. 105: 133-141.

Kirkby, E. A. \& A. D. Hughes, 1970. Some aspects of ammonium and nitrate nutrition in plant metabolism. In: E. A. Kirkby (Ed.), Nitrogen nutrition of the plant, p. 69-77. University of Leeds.

Loué, A., 1970. Fumure et qualité. Doc. tech, S.C.P.A. 7.

Michael, G., P. Martin \& I. Owassia, 1970. The uptake of ammonium and nitrate from labelled ammonium nitrate in relation to the carbohydrate supply of the roots. In: E. A. Kirkby (Ed.), Nitrogen nutrition of the plant, p. 22-29. University of Leeds.

Moore, S., 1957. Aqueous dimethyl sulfoxide as solvent for the ninhydrin reaction. J. biol. Chem. 243: $6281-6283$.

Mulder, E. G., 1956. Stikstof in de plan. Meded. Dir. Tuinb. 19: 673-690.

Pitman, M. G., 1970. Active $\mathbf{H}+$ efflux from cells of low salt barley roots during salt accumulation. Pl. Physiol. 45: 787-790.

Prianishnikov, D. N., 1951. Nitrogen in the life of plants. Kramer Business Service Inc., Madison, Wisconsin.

Prummel, J., 1966. Nitraat en oxaalzuur in spinazie in verband met de gezondheid. Rapp. Inst. Bodemvruchtbaarheid Groningen, 10.

Rosen, H., 1957. A modified ninhydrin colorimetric analysis for amino acids. Arch. Biochem. Biophys. $67: 10-15$.

Schuffelen, A. C., M. Rosanow \& A. van Diest, 1965. Plant composition and mineral nutrition. Symposium C.I.C.R.A., Paris.

Simon, W. et al., 1970. Ion selective sensors. Angew. Chem., int. Ed. 9: $445-455$.

Slangen, J. H. G., 1971. Intermitterende voeding bij tarwe. Thesis, Wageningen.

Tuil, H. D. W. van, 1965. Organic salts in plants in relation to nutrition and growth. Thesis, Wageningen.

Wakiuchi, N., H. Matsumoto \& E. Takahashi, 1971. Changes of some enzyme activities of cucumber during ammonium toxicity. Physiologia Pl. 24: 248-253.

Weissman, G. S., 1964. Effect of ammonium and nitrate nutrition on protein level and exudate composition. Pl. Physiol, 39: 947-952.

Weissman, G. S., 1972. Influence of ammonium and nitrate nutrition on enzymatic activity in soybean and sunflower. Pl. Physiol, 49: 138-141.

Welte, E. \& W. Werner, 1962. Ionenaustaucherversuche über die Beeinflussung der Kationenaufnahme der Pflanzen durch die Stickstoff-form. Agrochimica 6: 337-348.

Wit, C. T. de, W. Dijkshoorn \& J. C. Noggle, 1963. Ionic balance and growth of plants. Versl. landbouwk. Onderz. 69.15 .

Zsoldos, F., 1962. The influence of $\mathrm{NH}_{4}+$ on the growth of rice plants. Acta bot. Acad. Sci. Hung. 8: $213-218$

The University of the South Pacific, Laucala Bay, Suva, Fiji, urgently needs back numbers of the journal Plant and Soil, viz. Vol. 1-31. The University is prepared to pay for packing and freighting. Please write to Royal Netherlands Society for Agricultural Science, P.O.B. 79, Wageningen. 